\title{
Development of blended learning model in numerical method course
}

\author{
Siti Aminah* \\ Sekolah Tinggi Informatika dan Komputer Indonesia, Jl. Raya Tidar No.100 Malang, Indonesia
}

\begin{tabular}{|c|c|}
\hline A R T I C LE I N F O & A B S T R A C T \\
\hline $\begin{array}{l}\text { Original Article } \\
\text { doi: } 10.18860 / \text { ijtlm.v } 1 \text { ii } 2.5908\end{array}$ & $\begin{array}{l}\text { The aim of this study is to develop a blended learning system with } \\
\text { two stay two stray using problem-based learning worksheet. The }\end{array}$ \\
\hline $\begin{array}{l}\text { Keywords: } \\
\text { Blended Learning, Numerical } \\
\text { Method, Problem-Based } \\
\text { Learning, Two Stay Two Stray }\end{array}$ & $\begin{array}{l}\text { study is a research and development. The study used four D models } \\
\text { covering define, design, development and disseminate stage. Then, } \\
\text { the system of the blended learning model and problem-based } \\
\text { learning worksheet were validated by two validators with valid } \\
\text { criteria and some revisions. For test efficiency, data were processed } \\
\text { using a paired sample T-test. The result showed that the average } \\
\text { learning outcome improved after the implementation of a blended } \\
\text { learning system in which the outcomes of earning significantly } \\
\text { improved. }\end{array}$ \\
\hline
\end{tabular}

(C) 2018 IJTLM. All rights reserved.

*Corresponding author.
E-mail: sitiaminah@stiki.ac.id

How to cite: Aminah, S. (2018). Development of blended learning model in numerical method course. International Journal on Teaching and Learning Mathematics, 1(2), 66-75.

\section{INTRODUCTION}

Mathematics is an important topic for engineering students. They need some understanding of mathematics in order to do their professional work and develop a tool such as a computer program. They must have good senses of school mathematics, particularly applied mathematics as well as mathematical reasoning. Mathematics can help them to understand how the program computer work (Callaghan et al., 2018; Clements, 2000; Foster et al., 2016; Sigurdson \& Petersen, 2017). One of the mathematical topics studied by students is numerical method.

Students who who suffer from mathematical disabilities tend to believe that their learning strategies are not suitable. The impact is that they forget it faster (Fahsl, 2007; Lambert, 2015; Steele, 2002). Informatics engineering students get difficulties to learn numerical method courses as indicated by the students' low outcomes of learning in numerical method course. These conditions may come from the lecturer's learning mode or the students' inability to understand the topic, so the students have a tendency to be passive in the teaching-learning process (Kristanti et al., 2018).

Problem-based learning (PBL) can motivate students to work with exemplary problems that are typical for the professions in which the students would work after graduation (Park \& Ertmer, 2007; Tan, Van der Molen, \& Schmidt, 2016). Also, PBL was effective in mathematics learning (Argaw et al., 2017; Farhan \& Retnawati, 2014). Basically, informatics engineering students always work with computer program languages. Thus, it is important to apply PBL as a model learning in numeric method to produce computer programs that use algorithms in numerical methods.

Numerical method requires complex mathematical calculations, so students are not motivated to learn this course because they are afraid of mathematics. Therefore, numerical 
method learning uses the worksheet based on PBL to motivate students to learn a concept based on the knowledge that they know (Argaw, Haile, Ayalew, \& Kuma, 2017; Harun, Yusof, Jamaludin, \& Hassan, 2012; Helmi, Yusof, Phang, Mohammad, \& Abu, 2013). In this study, the worksheet is based on the characteristics of PBL adapted from Barrow and Tamblyn (Farhan \& retnawati, 2014) which is presented as a complex and real problem with one solution. Then, the problems are solved in groups and students take information through self-directed. It is hoped that the issues presented can enhance problem-solving abilities.

Two Stay Two Stray (TSTS) model is a cooperative learning developed by Spencer Kagan in 1992 in which students work together to share through visiting and responsible for the material obtained from the visit to explain with their own group (Lapohea, 2014; Maulana \& Hidayati, 2017). Each student in a group is encouraged to be responsible to work and socialize with others, so each student can understand all algorithms on numerical method. In addition, TSTS learning can increase learning outcomes (Hartriani \& Veronica, 2015; Maulana \& Hidayati, 2017) as it is effective to increase students' ability to learn mathematics (Hartriani \& Veronica, 2015).

In this research, TSTS done was blended learning by moodle, in asynchronously and synchronously. The moodle is called ebelajar. Students discuss their material asynchronously held in features forum in ebelajar. Each group member can only see the post of their own group in ebelajar, but invisible for another. In contrast, the learning activities done synchronously are sharing the results of discussion in class which would be shared with others through mutual friends visiting other groups.

Blended learning combined learning in synchronous with asynchronous learning with the goal of learning to walk effectively (Chaeruman, 2017). Blended learning has positive effect for learning outcome, attitudes toward studying in mathematics course (Lin, Tseng, \& Chiang, 2017), and give significant difference on students' perceptions (Umoh \& Akpan, 2014). In this study, students construct a concept on a worksheet based on PBL. Students share their ideas through TSTS learning model that was done using blended learning. It is hoped that this collaborative learning can give positive effect in improving students' learning outcomes through the development of blended learning with two stay two stray useing worksheet PBL in numeric method courses.

\section{METHOD}

This study is a research and development by adopting four D models (Thiagarajan, Semmel, \& Semmel, 1974) covering define, design, develop and disseminate as seen in Table 1.

Table 1. Stages of four D

\begin{tabular}{|c|c|}
\hline Stage & Researcher Activity \\
\hline \multicolumn{2}{|l|}{ Define Stage } \\
\hline Step 1. Front-End Analysis & $\begin{array}{l}\text { Analysing why students get difficulties in } \\
\text { learning mathematics }\end{array}$ \\
\hline Step 2. Learner Analysis & Characteristic analysis of student's cognitive \\
\hline Step 3. Concept Analysis & Material analysis \\
\hline Step 4. Task Analysis & $\begin{array}{l}\text { Theory analysis of PBL, TSTS, and blended } \\
\text { learning }\end{array}$ \\
\hline Step 5. Specifying Instructional Objective & $\begin{array}{l}\text { Identification purpose of learning method } \\
\text { numerical by PBL worksheet, TSTS model, and } \\
\text { blended learning }\end{array}$ \\
\hline Desig & \\
\hline Step 1. The Criterion-Referenced Test & Making question for pre-test, post-test and \\
\hline
\end{tabular}


International Journal on Teaching and Learning Mathematics

2018, Vol. 1, No. 2, pp. 66-75

P-ISSN: 2621-2188, E-ISSN: 2621-2196

Step 2. Media Selection

Step 3. Format Selection

Step 4. Initial Design

Development Stage

Step 1. Expert Appraisal

Step 2. Development Test

Disseminate Stage

Step 1. Validation Testing determine the assessment rubric for creating and presenting a programming

Determining media for blended learning with Moodle and worksheet-based criteria of PBL

Determining format of material and instruction of TSTS model in Moodle

Initial design of numerical method course by Moodle and PBL worksheet

Giving validator access numerical method course by Moodle, and validation sheet

Revision based validator suggestion, trial in

limited students, and revision

Analysis learning outcome of student after use blended learning

The instruments used were pre-test, post-test questions, sheet validation for the worksheet PBL and sheet validation for blended learning system in Moodle. The subjects were 34 students of numeric methods TI-A STIKI Malang divided into groups which were determined by the lecturer based on the results of pre-test in administered in the first week. Data from the validation test results were calculated by using the average score (Hobri, 2010) and the validity criteria (Parta, 2009) as shown in Table 2. Data processing of effective test using statistical test through normality test, homogeneity test, and paired sample T-test since the data were normally distributed.

Table 2. The Level of Validity

\begin{tabular}{cc}
\hline Interval & Level of Validity \\
\hline $2 \leq \bar{V}_{a} \leq 3$ & Valid \\
$1 \leq \bar{V}_{a}<2$ & Intermediate \\
$0 \leq \bar{V}_{a}<1$ & Invalid \\
\hline
\end{tabular}

\section{RESULTS AND DISCUSSION}

\subsection{Define Stage}

The Front-End Analysis

Many materials and the lack of time needed to study the numerical methods became obstacles in learning numerical methods. Traditional learning was not effective for this class. Learning numerical method related to calculations of complex mathematical made students unmotivated and afraid to learn it.

\section{The Learner Analysis}

Learner were students of Informatic Engineering 5th semester 2017/2018 in STIKI taking the course of numerical methods. Students in this class were generally weak in math.

\section{Concept analyses}

Sub-material in the system of nonlinear equations were the bisection method, false position method, fixed point method, Newton Raphson method, and the secant method. And sub-material of the system of linear equations is limited to Gaussian elimination method, Gauss Jordan elimination method, Jacobi iteration method, Gauss-Seidel iteration method, matrix inverse method, decomposition method, and Cramer method. 


\section{The Task Analysis}

The students accomplished their task on a worksheet in groups. Worksheet was prepared based on the characteristics of PBL, the problem presented was complex mathematical problems with one solution, the problem solved in groups, students gained information through self-directed, and the problem presented could enhance problem-solving abilities of students (Eser \& OzdamliI, 2016). Self-directed was reflected on the students' activities through the instruction structured in a worksheet. The problem-solving abilities were shown in a computer program that must be made by the student. A computer program created was the application of the calculation procedure of the method which had been studied. Example problem in systems of nonlinear equations worksheet was shown in Table 3.

Table 3. Examples of the problems in worksheet

\begin{tabular}{ll}
\hline Criteria problems in PBL & Examples of problems that appear in the worksheet PBL \\
\hline the problem presented is complex & One of the problems are presented in the asynchronous learning \\
mathematical problems $\quad$ with & $\begin{array}{l}\text { through ebelajar and worked in groups through discussion forum. } \\
\text { The initial problem }\end{array}$
\end{tabular}

having one solution

\section{The initial problem}

Find the roots of the equation $\mathrm{f}(\mathrm{x})=x^{3}+4 x^{2}-11 x-30$

with starting point $\mathrm{x}_{0}=1, \mathrm{x}_{1}=2$ and $\varepsilon=0.000001$ with the secant method!

the problem solved in groups

The initial problem solved by group through asynchronous learning use the feature discussion forum on ebelajar.

students gain information through The following is a guide for students in resolving one of the self-directed problems, namely determining formula $X_{r+1}$ use gradient and graph. These instructions appeared when students working group on the material secant method.

a. The red line is a tangent to the curve $f(x)$, To obtain the equation of the tangent line, we can use a derivative of the curve $f(x)$ at the point $X_{r}$ symbolized $f^{\prime}\left(X_{r}\right)$. In addition, we can get the equation of a tangent by using gradient. From these statements, we understand that $m=f^{\prime}\left(X_{r}\right)$

b. If we known point on the tangent line $\mathrm{AC}$ is $\mathrm{A}\left(X_{r+1}, 0\right)$ and $\mathrm{C}$ $\left(X_{r}, f\left(X_{r}\right)\right)$, then find the gradient of the tangent $\mathrm{AC}$ !

If known point $\mathrm{A}\left(x_{1}, y_{1}\right)$ and $\mathrm{B}\left(x_{2}, y_{2}\right)$, the gradient of the line $A B$ is $\frac{y_{2}-y_{1}}{x_{2}-x_{1}}$

c. If we known point on the tangent line $\mathrm{BC}$ is $\mathrm{B}$ $\left(X_{r-1}, f\left(X_{r-1}\right)\right)$ and $\mathrm{C}\left(X_{r}, f\left(X_{r}\right)\right.$, then find the gradient of the Etc.. tangent $\mathrm{BC}$ !

The problem presented can This problem was presented in the end of semester through a enhance problem-solving abilities of students

computer program presented by groups.

\section{Advanced problem}

Make a programming using Java to display the solutions of systems of nonlinear equations for polynomial function. Then demonstrate the results of your product in front of the class. Explain that the source code has been made is a representation of each step in the method of the non-linear system of equations.

Here is the division of the project should be done every group.

1. For group A procedure using bisection method

2. For group $\mathrm{C}$ using the procedure set point Iteration Method Etc

\section{Specifying Instructional Objective}

Specifying instructional objective was to find indicators and achievement of objectives. The objectives of learning are (1) understand the solution of system of nonlinear equations with sub- 
material discussion of bisection method, false position method, fixed point method, Newton Raphson method and the secant method (2) create and present a programming that apply the solutions of system of nonlinear equations (3) understand the solution of the system of linear equations with sub-material discussion of Gaussian elimination method, Gauss Jordan elimination method, Jacobi iteration method, Gauss-Seidel iteration method, matrix inverse method, decomposition method, and Cramer method and (4) create and present a programming that applies the solution of system of linear equations.

\subsection{Design Stage}

The Constructing-Referenced Test

The constructing-referenced test was created pretest, posttest and determine the assessment rubric for creating and presenting a programming.

\section{Media Selection}

Media selection was using Moodle and PBL worksheet as a learning medium.

\section{Format Selection}

In the introduction contains titles of courses, lecture, greeting, course descriptions, competencies, learning plan, implementation plan, and assessment plan. In the learning content contain pretest, the initial information, reading materials, videos, assignments, and quizzes in synchronous learning instruction (posttest) (Chaeruman, 2017). The concluding part contained the questionnaire for the student after numeric method learning.

\section{Initial Design}

Here is an example of the display in the introduction. The introductory section contained titles of courses, lecture, greeting, course descriptions, competencies, learning plan, implementation plan, and assessment plan.

Title of Course is "Metode Numerik". Identity of lecturer contained photo, email, and phone number of the lecturer. Thus, student can contact their lecturer via the information in ebelajar. Greeting statements contained welcome statement to the course, such as 'welcome to the numerical course' or 'hello student', etc. And course descripton told about benefits of learning numerical method in computer programming.

The lecturer showed the competencies in learning numerical method, and the students learned sequential theory topics, such as error, nonlinear equation system, linear equation system, regression, interpolation, differential numeric. The theories that had been discussed were applied in the computer programs. So, the competence in numerical method was that the students were able to do calculations using the concept of numerical methods, then apply the concept by making a computer program and reporting it. The lecturer showed mapping of objective learning and topic learned in the fist semester. Implementation plan covered the schedule of learning numerical method in one semester.

Learning plan told about the learning strategy done in cooperative learning namely Two Stay Two Stray. Every student must access ebelajar.stiki.ac.id. Every student must be active to give opinion in forum discussion in ebelajar. Every group task must be uploaded in ebelajar. Individual task consists of two individual tasks and two online quiz in one semester. In the midterm and final exams, every student must apply numerical method in computer programming. 
In addition, assessment plan section showed that final score from $35 \%$ middle exams score, $25 \%$ assignment score, and $40 \%$ final exams score. The assignments score consists of $10 \%$ average score of 4 group task, $10 \%$ average score of 2 quiz, and 5\% activeness score.

Figure 1 is an example of the display in the learning content divided into two parts: the instruction to learning asynchronous and synchronous learning. Asynchronous learning began with reading the introduction and understand video on finding the root in quadratic and cubic equations for 1 week. Then the students must work on pretest with a minimum value of 50. If the result of pretest past 65, then they can insert to a discussion forum. The discussion forum on setting question and answer with a separate group in Figure 1.

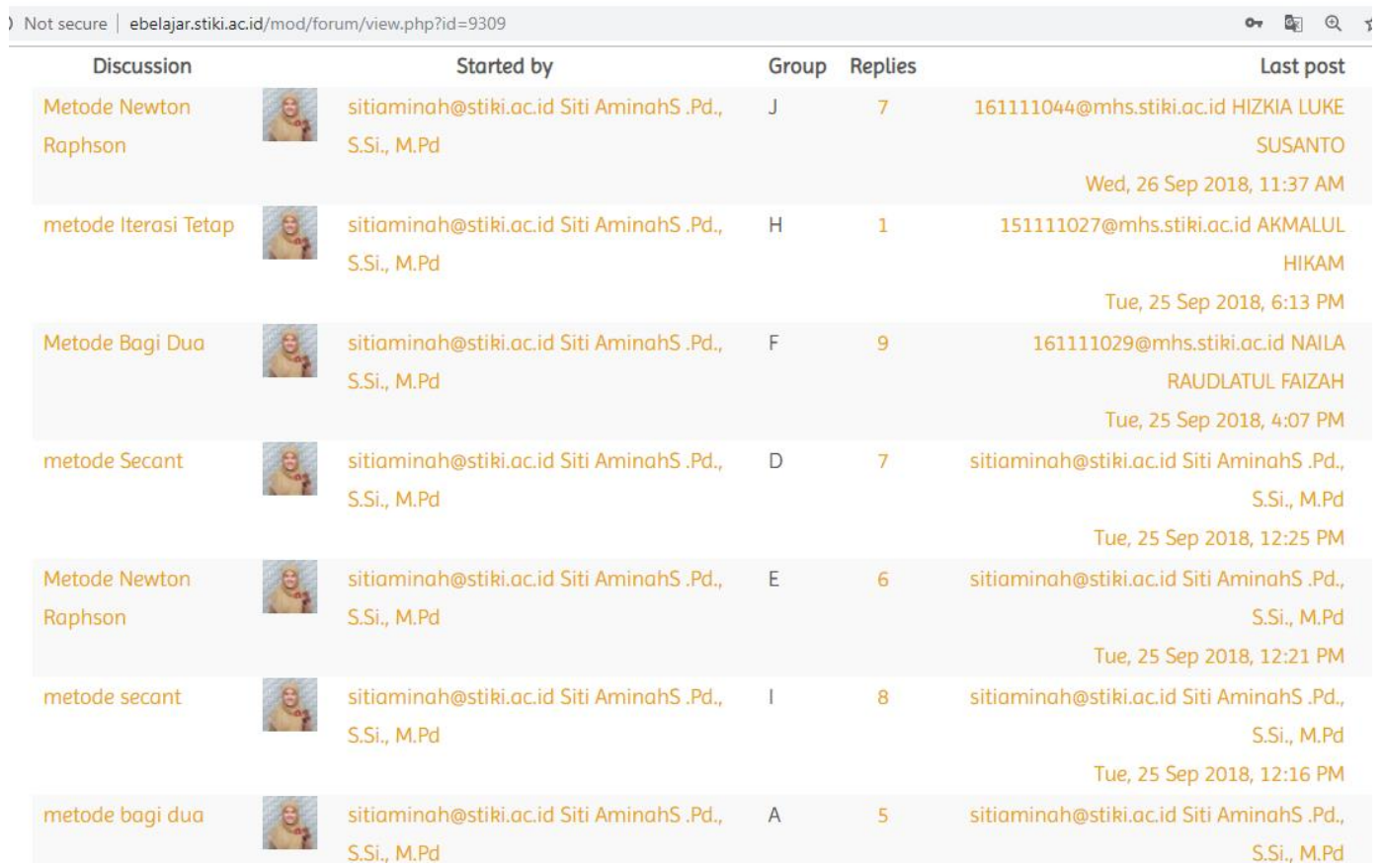

Figure 1. Example of the display on discussion activity asynchronously with separate groups

TSTS learning was done asynchronously and synchronously. The students discussed the materials through a forum in ebelajar during one week. When completing asynchronous learning, the students learned synchronously at a predetermined time as presented in Table 4. The purpose of this learning was that students must share a method they learned. So, the goal of TSTS learning was all student can understand all the methods at each material. Table 4 is one example of steps TSTS learning synchronously.

Table 4. Step of nonlinier equation learning synchronously

\begin{tabular}{|c|c|c|c|}
\hline \multicolumn{2}{|c|}{$\begin{array}{l}\text { Submaterial } \\
\text { Material }\end{array}$} & \multicolumn{2}{|c|}{$\begin{array}{l}\text { The nonlinear equation with open method and close method } \\
\text { The bisection method, the false position method, the fixed } \\
\text { point method, the newton raphson method, and the secant } \\
\text { method } \\
\text { : Two Stay Two Stray }\end{array}$} \\
\hline Stage & Learning Activity & & Duration \\
\hline Opening & $\begin{array}{l}\text { - } \\
\text { - } \\
\text { - } \\
\text { Lecturer gave } \\
\text { material when } \\
\text { - } \\
\text { Lecturer gave }\end{array}$ & $\begin{array}{l}\text { oreciation } \\
d \text { that learning was done with two stay two stray } \\
d \text { that every member in group understood the } \\
\text { ey learned in ebelajar asynchronously } \\
\text { tivation to student }\end{array}$ & $10^{\prime}$ \\
\hline $\begin{array}{l}\text { Core } \\
\text { activity }\end{array}$ & $\begin{array}{ll}\text { - } & \text { Member of gr } \\
\text { - } & \text { Host served gu }\end{array}$ & $\begin{array}{l}\mathrm{p} \text { was divided by } 2 \text { part: as guest and as host. } \\
\text { st by explaining them material }\end{array}$ & $30^{\prime}$ \\
\hline
\end{tabular}


- Guest visited other groups. They learn about material other groups. 60'

- Guest was back to group themselves to explain material that they hade learned to members of groups.

Closing

- Students concluded together the results of discussion

After the students learned the numerical method, they applied it in the computer program. The computer program would be presented by every group in the mid-term test after each student finished the quiz as a posttest in 2 hours by ebelajar synchronously. The posttest was used to measure their understanding. After learning nonliniar equation topic, the students filled a questionnaire containing the response/feedback after they joined this blended learning.

\subsection{Development Stage}

\section{Validation Expert}

This stage provided a blended learning model that had been revised after obtaining an evaluation of two mathematics lecturers at STIKI Malang who acted as the validators. The average score of all validators for worksheet PBL was 2.13 and included in the criteria valid. The average score of all validators for the blended learning model is 2.47 , and it implied that the blended learning model was valid.

\section{Development test}

After the experts provided the results of the assessment, the researcher revised method numerical courses in Moodle. The suggestion of validation was used to make better numerical courses in Moodle before applying a to students of STIKI Malang. Then, the researcher revised method numerical courses in Moodle again covering a question whether sentences in Moodle and in the worksheet were easy to understand and free from connotative meaning.

\subsection{Disseminate Stage}

In this stage, there was only one activity namely validation testing.

\section{Validation Testing}

There was an effective test results obtained from pretest and posttest data. Before the paired sample T-test, the normality of the scores was tested using statistical software SPSS as presented in Table 5 .

Table 5. The result of normality test

\begin{tabular}{llr}
\hline & \multicolumn{2}{c}{ Unstandardized Residual } \\
\hline Normal Parameters & Mean & 34 \\
& Std. Deviation & 0.0000000 \\
Most Extreme Difference & Absolute & 10.19348310 \\
& Positive & 0.095 \\
& Negative & 0.095 \\
Kolmogorov-Smirnov Z & & -0.95 \\
Asymp. Sig (2-tailed) & & 0.556 \\
& & 0.917 \\
\hline
\end{tabular}

In this study, the basis for a decision on the normality test was based on the value Asymp. Sig (2-tailed). If Asymp. Sig (2-tailed)> 0.05, the data was the normal distribution, and viceversa. Table 1 showed that the result of the statistical computation obtained Asymp. Sig (2tailed) of 0.917 . Because 0.917 was greater than 0.05 , then the data in this study was normally 
International Journal on Teaching and Learning Mathematics

2018, Vol. 1, No. 2, pp. 66-75

P-ISSN: 2621-2188, E-ISSN: 2621-2196

distributed. Furthermore, the homogeneity was tested with SPSS. The result of the homogeneity test can be seen in Table 6 .

Table 6. Result of homogeneity test

\begin{tabular}{cccc}
\hline Levene Statistic & df1 & df2 & Sig. \\
\hline 0.837 & 1 & 66 & 0.364 \\
\hline
\end{tabular}

To conclude whether they were homogeneous, it was said that if the Sig. value was $<0.05$, they weren't homogeneous, and vice-versa. From Table 2, it was stated that the Significance value was 0.346 . Because 0.346 was greater than 0.05 , then the data in the study were homogeneous.

Because the data were normally distributed and homogeneous, then paired sample T-test with statistical software was applied as seen in Table 7.

Table 7. Results of paired samples t-test

\begin{tabular}{|c|c|c|c|c|c|c|c|c|}
\hline \multicolumn{9}{|c|}{ Paired Samples Statistics } \\
\hline & \multicolumn{2}{|c|}{ Mean } & \multicolumn{2}{|c|}{$\mathrm{N}$} & \multicolumn{2}{|c|}{ Std. Deviation } & \multicolumn{2}{|c|}{ Std. Error Mean } \\
\hline Pair 1 Pretest & \multicolumn{2}{|c|}{48.24} & \multicolumn{2}{|c|}{34} & \multicolumn{2}{|c|}{17.403} & \multicolumn{2}{|c|}{2.985} \\
\hline Posttest & \multicolumn{2}{|c|}{61.32} & \multicolumn{2}{|c|}{34} & \multicolumn{2}{|c|}{11.801} & \multicolumn{2}{|c|}{2.024} \\
\hline \multicolumn{9}{|c|}{ Paired Samples Correlations } \\
\hline & \multicolumn{3}{|c|}{$\mathrm{N}$} & \multicolumn{2}{|c|}{ Correlation } & & \multicolumn{2}{|c|}{ Sig. } \\
\hline $\begin{array}{cc}\text { Pair } 1 & \text { Pretest \& } \\
& \text { Posttest }\end{array}$ & \multicolumn{2}{|r|}{34} & & \multicolumn{2}{|c|}{0.504} & & \multicolumn{2}{|c|}{0.002} \\
\hline \multicolumn{9}{|l|}{ Paired Sample Test } \\
\hline & \multicolumn{8}{|c|}{ Paired Differences } \\
\hline & \multirow[t]{2}{*}{ Mean } & \multirow[t]{2}{*}{$\begin{array}{c}\text { Std. } \\
\text { Deviation }\end{array}$} & $\begin{array}{l}\text { Std. } \\
\text { Error } \\
\text { Mean }\end{array}$ & \multicolumn{2}{|c|}{$\begin{array}{l}95 \% \text { Confidence } \\
\text { Interval of the } \\
\text { Difference }\end{array}$} & \multirow[t]{2}{*}{$\mathrm{t}$} & \multirow[t]{2}{*}{ df } & \multirow[t]{2}{*}{$\begin{array}{l}\text { Sig (2- } \\
\text { tailed) }\end{array}$} \\
\hline & & & & Lower & Upper & & & \\
\hline $\begin{array}{l}\text { Pair } 1 \text { Pretest \& } \\
\text { Posttest }\end{array}$ & -13.088 & 15.335 & 2.630 & -18.439 & -7.737 & -4.977 & 33 & 0.000 \\
\hline
\end{tabular}

In Table 3, the results of the paired sample T-test were divided into 3 parts. The first part was the paired sample statistics. The mean pretest was 48.24 with a standard deviation of 17 403. While the mean posttest was 61.32 with a standard deviation of 11.801 . This means that the average learning outcome improved after learning to use a blended learning system.

In the second part is paired samples correlations. In this section, the correlation value was 0.504 obtained by the Sig. 0002 . Because of $0.002<0.05$, then between before and after learning with blended learning system significantly related.

The third section was the paired sample test. $\mathrm{H}_{0}$ in this study was an average of learning outcomes after and before use blended learning systems were the same. $\mathrm{H}_{1}$ in this study was an average of learning outcomes after and before use blended learning systems were different. Decision-making in this study is based on a comparison of $t$ and $t_{\text {table. }}$. If $t>t_{\text {table, }}$, then $\mathrm{H}_{0}$ is rejected. If $\mathrm{t}<\mathrm{t}_{\text {table }}$, then $\mathrm{H}_{0}$ is accepted. The calculation showed $t=\frac{d}{s / \sqrt{n}}=\frac{13.088}{15.335 / \sqrt{34}}=4.976$. While for the $5 \%$ significance level and the degree of freedom $34-1=33$, it was $\mathrm{t}_{\text {table }}=\mathrm{t}_{0.025,33}$ $=2,035$. Because $t>t_{\text {table, }}$, then $\mathrm{H}_{0}$ is rejected. It means that the average of learning outcome after and before using a blended learning system was different. The blended learning system gave positive effect to srudents' learning outcomes. This finding is in line with several studies that reported significant impact of blended learning toward learning outcomes or attitudes (Balentyne \& Varga, 2017; Lin, Tseng, \& Chiang, 2017; Yudt, \& Columba, 2017). 


\section{CONCLUSION}

This research focused on blended learning model in numerical method course. Learning outcome before and after use blended learning model was different. The average learning outcomes improved after the treatment of a blended learning model. The correlation between before and after learning used blended learning model significantly related. So, blended learning model can give positive influence in learning numerical method course. Blended learning model can give influence in process standards mathematics, like as problem solving, reasoning and proof, communication, connections, representations.

\section{REFERENCES}

Argaw, A. S., Haile, B. B., Ayalew, B. T., \& Kuma, S. G. (2017). The effect of Problem Based Learning (PBL) instruction on students' motivation and problem solving skills of physics. Eurasia Journal of Mathematics, Science and Technology Education, 13(3), 857-871. https://doi.org/10.12973/eurasia.2017.00647a

Balentyne, P., \& Varga, M. A. (2017). Attitudes and achievement in a self-paced blended Mathematics Course. Journal of Online Learning Research, 3(1), 55-72.

Callaghan, M. N., Long, J. J., Van Es, E. A., Reich, S. M., \& Rutherford, T. (2018). How teachers integrate a math computer game: Professional development use, teaching practices, and student achievement. Journal of Computer Assisted Learning, 34(1), 10-19.

Chaeruman, U. A. (2017). PEDATI, model desain sistem pembelajaran blended. Jakarta: Direktorat Pembelajaran Kementrian Riset, Teknologi dan Pendidikan Tinggi.

Clements, D. H. (2000). From exercises and tasks to problems and projects: Unique contributions of computers to innovative mathematics education. The Journal of Mathematical Behavior, 19(1), 9-47.

Eser, C., \& OzdamliI, F. (2016). Features and characteristics of problem based learning. Cypriot Journal of Educational Sciencies, 11(4), 195-202. https://doi.org/10.18844/cjes.v11i4.1296

Fahsl, A. J. (2007). Mathematics accommodations for all students. Intervention in School and Clinic, 42(4), 198-203.

Farhan, M., \& Retnawati, H. (2014). Keefektifan PBL dan IBL ditinjau dari prestasi belajar. Jurnal Riset Pendidikan Matematika, 1(2), 227-240.

Foster, M. E., Anthony, J. L., Clements, D. H., Sarama, J., \& Williams, J. M. (2016). Improving mathematics learning of kindergarten students through computer-assisted instruction. Journal for Research in Mathematics Education, 47(3), 206-232.

Hartriani, N., \& Veronica, R. B. (2015). Keefektifan model pembelajaran two stay two stray realistic mathematics education. Unnes Journal of Mathematics Education, 4(1), 69-76.

Harun, N. F., Yusof, K. M., Jamaludin, M. Z., \& Hassan, S. A. H. S. (2012). Motivation in problem-based learning implementation. Procedia - Social and Behavioral Sciences, 56(Ictlhe), 233-242. https://doi.org/10.1016/j.sbspro.2012.09.650

Helmi, S. A., Yusof, K. M., Phang, F. A., Mohammad, S., \& Abu, M. S. (2013). Motivation and learning strategies: Promising outcomes of cooperative problem-based learning. The 4th International Research Symposium on Problem-Based Learning (IRSPBL) 2013 Motivation (pp. 216-221). https://doi.org/10.13140/RG.2.1.1347.7843

Hobri. (2010). Metodologi penelitian pengembangan: Aplikasi pada penelitian pendidikan Indonesia. Jember: Pena Salsabila. 
Kristanti, F., Ainy, C., Shoffa, S., Khabibah, S., \& Amin, S. M. (2018). Developing creativeproblem-solving-based student worksheets for transformation geometry course. International Journal on Teaching and Learning Mathematics, 1(1), 13-23. https://doi.org/10.18860/ijtlm.v1i1.5581

Lambert, R. (2015). Constructing and resisting disability in mathematics classrooms: A case study exploring the impact of different pedagogies. Educational Studies in Mathematics, 89(1), 1-18.

Lapohea, A. Z. (2014). Penerapan Model Pembelajaran Kooperatif Tipe Two Stay Two Stray untuk Meningkatkan Hasil Belajar Siswa pada Materi Logika Matematika. Jurnal Elektronik Pendidikan Matematika Tadulako, 1(2), 133-145.

Lin, Y. W., Tseng, C. L., \& Chiang, P. J. (2017). The effect of blended learning in mathematics course. Eurasia Journal of Mathematics, Science and Technology Education, 13(3), 741770. https://doi.org/10.12973/eurasia.2017.00641a

Maulana, M., \& Hidayati, N. A. (2017). Two stay two stray cooperative learning model in mathematics learning outcomes. Jurnal Daya Matematis, 5(3), 354-358. https://doi.org/10.26858/jds.v5i3.4842

Park, S. H., \& Ertmer, P. A. (2007). Impact of problem-based learning (PBL) on teachers' beliefs regarding technology use. Journal of Research on Technology In Education, 40(2), 247-267.

Parta, I. N. (2009). Pengembangan model pembelajaran inquiry untuk penghalusan pengetahuan matematika mahasiswa calon guru melalui pengajuan pertanyaan. Surabaya: Universitas Negeri Surabaya.

Sigurdson, N., \& Petersen, A. (2017). Student perspectives on mathematics in computer science. In Proceedings of the 17th Koli Calling International Conference on Computing Education Research (pp. 108-117).

Steele, M. M. (2002). Strategies for helping students who have learning disabilities in mathematics. Mathematics Teaching in the Middle School, 8(3), 140-143.

Tan, C. P., Van der Molen, H. T., \& Schmidt, H. G. (2016). To what extent does problem-based learning contribute to students' professional identity development?. Teaching and Teacher Education, 54, 54-64.

Thiagarajan, S., Semmel, D. S., \& Semmel, M. I. (1974). Instructional development for training teacher of exceptional children. Reston, VA: Council for Exceptional Children.

Umoh, J. B., \& Akpan, E. T. (2014). Challenges of blended e-learning tools in mathematics: Students' perspectives University of Uyo. Journal of Education and Learning, 3(4), 60-70. https://doi.org/10.5539/jel.v3n4p60

Yudt, K., \& Columba, L. (2017). The effects of blended learning in pre-service elementary mathematics teachers' performance and attitude. National Teacher Education Journal, 10(1), 17-25. 